\title{
Tinjauan Yuridis Penyalahgunaan Wewenang Oleh Pemerintah Dalam Kontrak Pengadaan Barang Dan Jasa (Studi Putusan No 37/PID.SUS-TPK/2015/PN/Mtr)
}

\author{
Ashari $^{1}$, Geatriana Dewi ${ }^{2}$, fadri Sanapiah ${ }^{3}$ \\ 1,2,3 Institut Ilmu Sosial Dan Ilmu Budaya Samawa Rea (IISBUD SAREA) \\ Email:ashariari@gmail.com, geatrianadewi86@gmail.com, fadrisanapiah@gmail.com
}

\begin{abstract}
Abstrak
Berbagai penyimpangan kerap terjadi dalam proses pengadaan barang dan jasa oleh pemerintah dalam menjalankan tugas dan jabatannya sesuai dengan kewenangannya,namun terdapat beberapa pandangan mengenai penyalahgunaan wewenang dalam prespektif hukum administrasi negara (pasal 17 UU No 30/ 2014 tentang administrasi pemerintah ) dan hukum pidana (pasal 3 UU No 20/2001 tentang tindak pidana korupsi). Tujuan peneltian ini untuk mengetahui pengaturan penyalahgunaan wewenang oleh pemerintah dalam UU No 30/2014 dan UU No 20/2001, dan bentuk penyalahgunaan wewenang dalam pengadaan barang dan jasa. Jenis penelitian, yuridis normatif dengan pendekatan perundang-undangan dan kasus. Hasil penelitian, yang dikategorikan sebagai tindakan menyalahgunakan wewenang dalam UU No 30/2014 adalah perbuatan yang menyimpang dari tujuan pemberian kewenangan, asas legalitas dan asas-asas umum pemerintahan yang baik, sedangkan tindakan menyalahgunakan wewenang dalam UU No 20/2001 tidak harus selalu berupa dikeluarkannya keputusan yang bertentangan atau menyalahi suatu aturan. Cukup perbuatan itu melanggar aturan tertulis sebagai dasar kewenangannya, memiliki maksud yang menyimpang, dan berpotensi merugikan Negara. Bentuk penyalahgunaan wewenang pada tahap penunjukan pemenang, tahap penandatangan kontrak yang terjadi dalam bentuk surat penunjukan yang tidak lengkap, dan tahap Penyerahan Barang dan Jasa
\end{abstract}

Kata Kunci: penyalahgunaan wewenang, pemerintah, barang dan jasa

\begin{abstract}
Abstrac
Various irregularities often occur in the process of procuring goods and services by the government in carrying out their duties and positions in accordance with their authority, but there are several views regarding abuse of authority in the perspective of state administrative law (article 17 of Law No. 30/2014 on government administration) and criminal law (article 17). 3 Law No. 20/2001 on criminal acts of corruption). The purpose of this research is to determine the regulation of abuse of power by the government in Law No. 30/2014 and Law No. 20/2001, and forms of abuse of authority in the procurement of goods and services. This type of research, juridical normative with the approach of legislation and cases. The results of the research, which are categorized as acts of abuse of authority in Law No. 30/2014 are acts that deviate from the purpose of granting authority, legality principles and general principles of good governance, while acts of abusing authority in Law No. 20/2001 do not always involve issuing them. decisions that contradict or violate a rule. It is enough that the act violates written rules as the basis of its authority, has a deviant intention, and has the potential to harm the State. The form of abuse of authority at the stage of appointing the winner, the contract signing stage that occurs in the form of an incomplete appointment letter, and the stage of delivery of goods and services
\end{abstract}

Keywords: abuse of authority, government, goods and services

\section{PENDAHULUAN}

Perkembangan perekonomian global saat ini begitu cepat, setiap negara dituntut untuk menyelenggarakan sistem perekonomiannya secara bersih dan transparan.Karena itu, pemerintah berkewajiban menyediakan kebutuhan rakyat berupa barang dan jasa, maupun 
pembangunan infrastruktur.Proses pembangunan dapat menimbulkan kemajuan dalam kehidupan masyarakat, selain itu dapat juga mengakibatkan perubahan kondisi sosial masyarakat yang memiliki dampak sosial negatif terutama menyangkut masalah tindak pidana terhadap penyalahgunaan wewenang, khususnya korupsi pada pengadaan barang dapat menimbulkan kerugian yang sangat besar terhadap pembangunan bangsa (Beridiansyah,2017:83)

Berbagai penyimpangan kerap terjadi dalam proses pengadaan barang dan jasa Pemerintah, ataupun di dalam pelaksanaan kontraknya, berbagai bentuk kesalahan kerap sekali dilakukan baik oleh pejabat maupun pelaksana di dalam menjalankan tugas dan jabatannya, tentunya sesuai dengan peraturan dan perundang-undangan yang sudah ada, kesalahan-kesalahan atau penyimpangan yang dilakukan tersebut harus dipertanggungjawabkan secara pribadi maupun yang berkaitan dengan jabatannya, Penyimpangan dalam proses pengadaan barang dan jasa yang merugikan keuangan negara merupakan salah satu bentuk tindak pidana korupsi.

Korupsi merupakan permasalahan yang hampir terjadi di seluruh belahan bumi (Donal Fariz,2014:9) namun korupsi lebih banyak dimaklumi oleh berbagai pihak dari pada memberantasnya, padahal tindak pidana korupsi adalah salah satu jenis kejahatan yang dapat menyentuh berbagai kepentingan yang menyangkut hak asasi, ideologi negara, perekonomian, keuangan negara, moral bangsa, dan sebagainya,yang merupakan perilaku jahat yang cenderung sulit untuk ditanggulangi.

Pengadaan barang dan jasa menurut Keppres No. 80 Tahun 2003 Tentang Pedoman Pelaksanaan Pengadaan barang/jasa pemerintah adalah kegiatan pengadaan barang/jasa yang dibiayai dengan APBN/APBD, baik yang dilaksanakan secara swakelola maupun oleh penyedia barang/jasa. Berdasarkan regulasi tersebut yang telah mengalami beberapa kali perubahan dan yang terakhir adalah Peraturan Presiden Nomor 4 Tahun2015, mensyaratkan bahwa pada prinsipnya pengadaan barang atau jasa oleh
Pemerintah harus dilakukan dengan cara tender.( Intan Mayasari dkk,2016:3)

Dalam kasus tender proyek pembuatan tempat pembuangan sampah (TPA) di Kecamatan Taliwang yang dikerjakan oleh PT Daya Hasta Multi Perkasa,kejaksaan memastikan kerugian Negara mencapai Rp 799 Juta, dari total pagu anggaran Rp 8 Miliar tahun anggaran 2013. Pelaksanaan proyek ini terindikasi menyimpang setelah penyidik bersama ahli konstruksi Universitas Mataram (Unram), menemukan dugaan kekurangan volume pada sejumlah item kegiatan pada proyek bersumber dari Kementerian Pekerjaan Umum. (https://globalfmlombok.com/read/2015/08/1 1/kasus-tpa-ksb-satu-orang-tersangka ditahan) Sehingga pengadilan tindak pidana korupsi mataram dalam putusan No 37/Pid.Sus-TPK/2015/PN/Mtr menjatuhi hukuman kepada Lalu Heri Gunawan sebagai pejabat pembuat komitmen (PPK) selama satu tahun dan denda lima puluh juta rupiah. Jika ditinjau dari segi pertanggungjawaban, dalam praktiknya pertanggungjawaban atas penyimpangan terhadap suatu proses kontrak dalam pengadaan barang dan jasa Pemerintah dilimpahkan kepada para pejabat dalam struktur pengadaan barang/jasa khususnya terhadap organisasi pengadaan barang dan jasa pemerintah seperti, Pengguna anggaran (PA) Kuasa Pengguna Anggaran (KPA) pejabat Pembuat Komitmen (PPK), dan unit layanan pengadaan (ULP). Hal ini tidak terlepas dari kedudukan dan jabatan Pejabat dalam struktur pengadaan barang dan jasa di Pemerintah yang memiliki tugas, fungsi dan kewenangan dan tanggung jawab yang sangat besar.(Murdian,2016:3)

Penyalahgunaan wewenang terdapat beberapa pandangan dalam prespektif Hukum Administrasi Negara dan Hukum Pidana. Berdasarkan Pasal 17 UndangUndang Nomor 30 Tahun 2014 tentang Administrasi Pemerintah dan dalam Pasal 3 UndangUndang Nomor 20 Tahun 2001 tentang Tindak Pidana Korupsi. Secara umum, fungsi hukum tindak pidana korupsi adalah untuk membatasi kekuasaan pejabat dalam bertindak serta melaksanakan tugas yang sudah diberikan oleh UndangUndang. 
Ketentuan dalam Pasal 3 UndangUndang Nomor 20 Tahun 2001 tentang perubahan pertama atas Undang-Undang Nomor 31 Tahun 1999 tenatng tindak pidana korupsi dimaksudkan untuk setiap orang yang dengan tujuan menguntungkan diri sendiri atau orang lain atau suatu korporasi, menyalahgunakan kewenangan, kesempatan atau sarana yang ada padanya, karena jabatan atau kedudukan yang dapat merugikan keuangan Negara.

Jika dilihat dari perspektif HAN, apabila tindakan yang dilakukan oleh pejabat itu melampaui batas kekuasaannya atau secara sewenang-wenang, maka tindakan tersebut juga dikatagorikan sebagai penyalahgunaan wewenang sesuai dalam Pasal 17 UndangUndang Nomor 30 Tahun 2014 tentang Administrasi Pemerintah bahwa pejabat di larang melakukan penyalahgunakan wewenang, bila terdapat kesalahan administratif yang menimbulkan kerugian keuangan negara pejabat tersebut hanya dapat mengajukan permohonan ke Pengadilan Tata Usaha Negara untuk memeriksa, dan memutuskan ada atau tidak ada unsur penyalahgunaan wewenang yang dilakukan oleh pejabat pemerintahan.

Dari latar belakang di atas dapat ditarik beberapa masalah antara lain:

1. Bagaimanakah Pengaturan Penyalahgunaan Wewenang Oleh Pemerintah Dalam Undang-Undang Nomor 30 Tahun 2014 Tentang Administrasi Pemerintahan Dan UndangUndang Nomor 20 Tahun 2001 Tentang Tindak Pidana Korupsi?

2. Bagaimanakah Bentuk Penyalahgunaan Wewenang Yang Dilakukan Oleh Pemerintah Dalam Kontrak Pengadaan Barang Dan Jasa?

\section{METODE PENELITIAN}

penelitian yang dipakai dalam penelitian ini adalah penelitian hukum normatif pada tingkatan teoritis, yaitu suatu prosedur penelitian ilmiah untuk menemukan kebenaran berdasarkan logika keilmuan hukum dari sisi normatifnya. Logika keilmuan yang ajeg dalam penelitian hukum normatif dibangun berdasarkan disiplin ilmiah dan cara-cara kerja ilmu hukum normaif, yaitu ilmu hukum yang obyeknya hukum itu sendiri (Johny Ibrhim,2010:57). Menurut Soerjono Soekanto dan Sri Mamudji penelitian hukum nomatif adalah penelitian hukum yang dilaksanakan dengan cara meneliti bahan pustaka atau data sekunder belaka(Soerjono Soekanto dan Sri Mamuji,2010:13), penelitian ini disebut juga penelitian hukum kepustakaan.

\begin{tabular}{|c|c|c|}
\hline $\begin{array}{c}\text { Metode } \\
\text { Penelitian }\end{array}$ & Uraian & $\begin{array}{l}\text { Indicator } \\
\text { Capian }\end{array}$ \\
\hline $\begin{array}{c}\text { Jenis } \\
\text { penelitian }\end{array}$ & $\begin{array}{l}\text { Penelitian } \\
\text { Normatif }\end{array}$ & $\begin{array}{c}\text { Jenis } \\
\text { penelitianny } \\
\text { a harus } \\
\text { bersifat } \\
\text { normatif - } \\
\text { empiris }\end{array}$ \\
\hline \multirow[t]{2}{*}{$\begin{array}{c}\text { Metode } \\
\text { pendekatan }\end{array}$} & $\begin{array}{l}\text { Pendektan } \\
\text { perundang } \\
\text { undangan }\end{array}$ & $\begin{array}{l}\text { Peraturan } \\
\text { perundang- } \\
\text { undangan } \\
\text { dan } \\
\text { peraturan } \\
\text { lainnya } \\
\text { sebagai } \\
\text { pendukung } \\
\end{array}$ \\
\hline & Kasus & $\begin{array}{l}\text { Putusan } \\
\text { pengadilan } \\
\text { yang telah } \\
\text { mempunyai } \\
\text { kekuatan } \\
\text { hukum tetap }\end{array}$ \\
\hline \multirow{2}{*}{$\begin{array}{c}\text { Sumber dan } \\
\text { jenis bahan } \\
\text { hukum }\end{array}$} & $\begin{array}{l}\text { Bahan hukum } \\
\text { primer }\end{array}$ & $\begin{array}{c}\text { Peraturan } \\
\text { perundang- } \\
\text { undangan, } \\
\text { buku, dan } \\
\text { pendapat } \\
\text { para ahli }\end{array}$ \\
\hline & $\begin{array}{l}\text { Bahan hukum } \\
\text { sekunder }\end{array}$ & $\begin{array}{c}\text { Putusan } \\
\text { pengadilan, } \\
\text { penelusuran } \\
\text { internet }\end{array}$ \\
\hline $\begin{array}{l}\text { Teknik } \\
\text { pengumpula } \\
\text { n bahan } \\
\text { hukum }\end{array}$ & $\begin{array}{c}\text { Studi } \\
\text { kepustakaan } \\
\text { dilakukan } \\
\text { dengan } \\
\text { mempelajari } \\
\text { buku-buku, } \\
\text { arsip, } \\
\text { dokumen dan } \\
\text { undang- }\end{array}$ & $\begin{array}{c}\text { Bahan- } \\
\text { bahan } \\
\text { hukum telah } \\
\text { diinventarisa } \\
\text { si dan } \\
\text { disusun } \\
\text { secara } \\
\text { sistematis }\end{array}$ \\
\hline
\end{tabular}




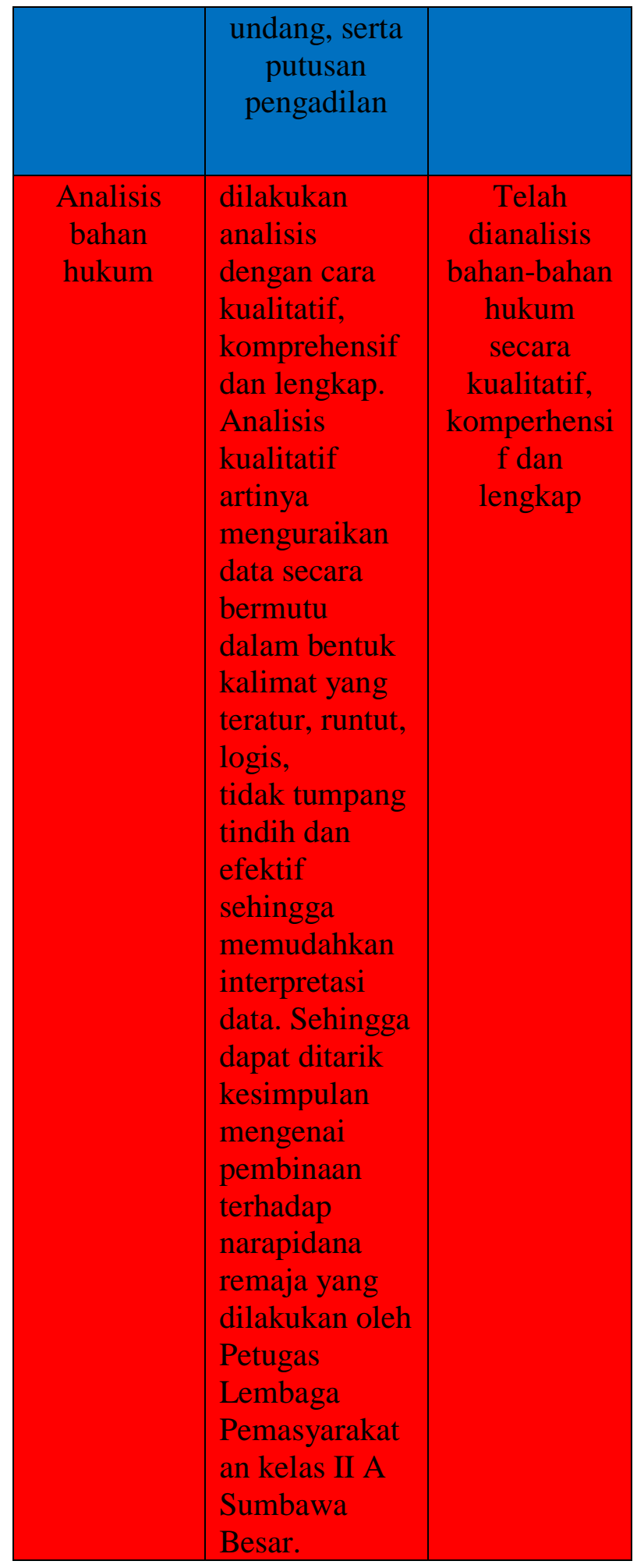

\section{HASIL DAN PEMBAHASAN}

\section{Pengaturan Penyalahgunaan Wewenang Pemerintah dalam Undang- Undang Nomor 30 tahun 2014 Tentang Administrasi Pemerintahan.}

penyalahgunaan wewenang memang menuai kontroversi apakah menjadi domain hukum administrasi negara dengan
Peradilan Tata Usaha Negara yang memiliki kompetensi absolutnya atau langsung ditarik ke ranah hukum pidana dalam hal ini Peradilan Umum. Selama ini pertanggungjawaban pidana pemegang jabatan dalam sistem hukum Indonesia, terutama kaitannya dengan tindak pidana korupsi, masih mendua didalam mengedepankan asas pidana lex specialis systematic atau logische specialiteit terhadap administratif penal law dan masih menerapkan Undang-Undang Pemberantasan Tindak Pidana Korupsi sebagai lex specialis (Indriyanto Seno Adji,2009:10)

Perdebatan seputar lembaga mana yang berwenang untuk menguji ada atau tidak adanya penyalahgunaan wewenang yang dilakukan oleh seorang pejabat publik memang merupakan perdebatan lama bahkan belum menuai kesepakatan di kalangan ahli hukum.Namun demikian lahirnya Undang-Undang Nomor 30 Tahun 2014 tentang Administrasi Pemerintahan setidaknya memberikan jawaban atas perdebatan tersebut. Menurut Supandi, penyalahgunaan wewenang (detournement de pouvoir) merupakan konsep hukum administrasi negara yang memang banyak menimbulkan salah paham dalam memaknainya. Dalam praktiknya detournement de pouvoir seringkali dicampuradukkan dengan perbuatan sewenang-wenang (willekeur/abus de droit), penyalahgunaan sarana dan kesempatan, melawan hukum (wederrechtelijkheid, onrechmatige daad), atau bahkan memperluasnya dengan setiap tindakan yang melanggar aturan atau kebijakan apapun dan di bidang apapun. Penggunaan konsep yang luas dan bebas ini pada akhirnya akan mudah menjadi senjata penyalahgunaan wewenang yang lain dan justru kebebasan bertindak pemerintah dalam menghadapi situasi konkret (freies ermessen) tiada artinya.

Terdapat bebrapa karakter atau ciri untuk menyebut bahwa telah terjadi penyalahgunaan wewenang antara lain:

1. menyimpang dari tujuan atau maksud dari suatu pemberian kewenangan; 
2. menyimpang dari tujuan atau maksud dalam kaitannya dengan asas legalitas;

3. menyimpang dari tujuan atau maksud dalam kaitannya dengan asas-asas umum pemerintahan yang baik.

Dalam perspektif hukum administrasi negara parameter yang membatasi gerak bebas kewenangan aparatur negara (discretionary power) adalah penyalahgunaan wewenang (detournement de pouvoir) dan sewenang-wenang (abus de droit).Sementara dalam konteks hukum pidana kriteria yang membatasi gerak bebas kewenangan aparatur negara disebut sebagai melawan hukum (wederechtelikheid) dan menyalahgunakan kewenangan.

Menurut Dian Puji N Simatupang, seorang pengambil kebijakan sebagai produk administrasi negara tidaklah dapat dipidana meskipun kebijakan tersebut salah. Seorang pengambil kebijakan dilekati dengan wewenang atributif. Wewenang yang diberikan oleh suatu peraturan kepada seorang pengambil kebijakan untuk mengambil kebijakan. Dalam mengambil kebijakan, seorang pengambil kebijakan harus mempertimbangkan manfaat atau tidaknya kebijakan tersebut demi kepentingan umum yang dilindunginya.Intinya, kebijakan yang diambil adalah pilihan terbaik pada situasi dan kondisi saat itu demi menjaga kepentingan umum. Yurisprudensi Mahkamah Agung Republik Indonesia Tahun 1966 setidaknya menjadi landasan landasan hukum yang memperkuat pendapat tersebut.Yurisprudensi ini menghapus pidana yang muncul dari tindakan kebijakan asalkan memenuhi tiga syarat, yaitu negara tidak dirugikan, seseorang atau badan hukum tidak diuntungkan secara melawan hukum, dan untuk pelayanan publik atau melindungi kepentingan umum.( http://www.hukumonline.com/berita/baca/lt 531b60851cc21/akademisi--pengambilkebijakan-publik-tak-dapat-dipidana.)

Senada dengan Dian Puji N Simatupang, Hikmahanto Juwana juga berpendapat bahwa kebijakan yang dianggap salah tidak serta merta diberikan sanksi pidana. Tidak semua kesalahan langsung dipidana.Kesalahan di ranah hukum administrasi negara harus dibedakan dengan hukum pidana. Kesalahan dalam mengambil kebijakan tidak bisa disamakan serta merta dengan perbuatan jahat sebagaimana diatur dalam hukum pidana.Hikmahanto menyebutkan hukum administrasi negara tidak mengenal sanksi pidana.Sanksi yang dikenal antara lain teguran lisan dan tertulis, penurunan pangkat, demosi, hingga pemecatan dengan tidak hormat.Kendati hukum administrasi negara tidak mengenal sanksi pidana, kebijakan yang salah tetap dapat dipidana. Kebijakan yang salah tersebut dikelompokkan setidak-tidaknya ada tiga macam, yaitu:

1. kebijakan serta keputusan dari pejabat yang melanggar Hak Asasi Manusia (HAM) berat, seperti kejahatan terhadap kemanusiaan, genosida, kejahatan perang, dan perang agresi;

2. kesalahan dalam pengambil kebijakan yang jelas-jelas telah dilarang dan diatur sanksi pidananya sebagaimana diatur dalam Pasal 165 UU Pertambangan Mineral dan Batubara, dan

3. kebijakan yang bersifat koruptif. Terkait dengan kebijakan yang bersifat koruptif ini, Hikmahanto sangat menekankan bahwa yang perlu diperhatikan bukanlah kebijakannya yang salah dan merugikan, tetapi niat jahat dari pengambil kebijakan ketika membuat kebijakan(http://www.hukumonline.com /berita/baca/lt531b60851cc21/akademisi --pengambil-kebijakan-publik-tak-dapatdipidana)

Rezim Undang-Undang Nomor 30 Tahun 2014 tentang Administrasi Pemerintahan menegaskan bahwa peradilan tata usaha negara merupakan lembaga peradilan yang memiliki kompetensi absolut untuk memeriksa ada atau tidak adanya dugaan penyalahgunaan wewenang. Jika selama ini seorang pejabat ditetapkan sebagai tersangka korupsi langsung diperiksa di peradilan umum, kini dengan rezim undang-undang ini seorang pejabat 
yang bersangkutan dapat mengajukan permohonan kepada Pengadilan Tata Usaha Negara terlebih dahulu untuk memeriksa dan memastikan ada atau tidak adanya unsur penyalahgunaan wewenang dalam keputusan dan/atau tindakan yang telah diambil. Ketentuan tersebut terdapat di dalam Pasal 21 Undang-Undang Nomor 30 Tahun 2014 tentang Administrasi Pemerintahan:

(a) Pengadilan berwenang menerima, memeriksa, dan memutuskan ada atau tidak ada unsur penyalahgunaan Wewenang yang dilakukan oleh Pejabat Pemerintahan;

(b) Badan dan/atau Pejabat Pemerintahan dapat mengajukan permohonan kepada Pengadilan untuk menilai ada atau tidak ada unsur penyalahgunaan Wewenang dalam Keputusan dan/atau Tindakan;

(c) Pengadilan wajib memutus permohonan sebagaimana dimaksud pada ayat (2) paling lama 21 (dua puluh satu) hari kerja sejak permohonan diajukan;

(d) Terhadap putusan Pengadilan sebagaimana dimaksud pada ayat (3) dapat diajukan banding ke Pengadilan Tinggi Tata Usaha Negara;

(e) Pengadilan Tinggi Tata Usaha Negara wajib memutus permohonan banding sebagaimana dimaksud pada ayat (4) paling lama 21 (dua puluh satu) hari kerja sejak permohonan banding diajukan;

(f) Putusan Pengadilan Tinggi Tata Usaha Negara sebagaimana dimaksud pada ayat (5) bersifat final dan mengikat.

Ketentuan pasal di atas dapat disebut sebagai payung hukum bagi pejabat Tata Usaha Negara dalam melakukan tindakan administrasi pemerintah.Ketentuan tersebut juga memberikan perlindungan terhadap Badan/Pajabat TUN di dalam membuat sebuah keputusan.Hal ini tentu sesuai dengan asas pre sumptio iustae causa atau asas praduga sah (rechmatig/ vermoeden van rechtmatigheid praesumptio iustae causa), di mana dalam asas ini mengandung makna bahwa setiap tindakan penguasa selalu harus dianggap sah (rechmatig) sampai ada pembatalannya (Philippus M. Hadjon dkk,2001:313).

Keberadaan Pasal 21 Undang-Undang Nomor 30 Tahun 2014 merupakan respon dari praktik yang selama ini diberlakukan, di mana terdapat kecenderungan aparat penegak hukum yang masih sangat positivsitik di dalam menjalankan fungsi pengawasan dan penegakkan hukum sehingga dugaan terjadinya penyalahgunaan wewenang kerap langsung beurujung pada proses hukum pidana. Situasi ini tentu berdampak pada ketidakpastian hukum di dalam perbuatan administrasi negara, yang pada gilirannya mengganggu kinerja pejabat administrasi negara.Dalam konteks yang lebih jauh pada gilirannya kerap menimbulkan character assacianation (pembunuhan karakter) terhadap praktek penyelenggaraan pemerintahan yang baik, lebih-lebih manakala dimanfaatkan oleh lawan politik untuk kepentingan politik.

Apabila merujuk definisi korupsi sebaimana bunyi Pasal 3 Undang-Undang Tindak Pidana Korupsi, unsur menyalahgunakan kewenangan memang menjadi salah satu rumusan tindak pidana korupsi. Namun demikian terdapat perbedaan antara unsur "menyalahgunakan kewenangan" sebagaimana tersebut dalam Pasal 3 Undang-Undang Nomor 31 Tahun 1999 tentang Pemberantasan Tindak Pidana Korupsi dengan unsur "penyalahgunaan kewenangan" sebagaimana disebut dalam Pasal 21 ayat (1) Undang-Undang Nomor 30 Tahun 2014 tentang Administrasi Pemerintahan. Menurut Supandi, ketentuan dalam Pasal 21 ayat (1) Undang-Undang Nomor 30 Tahun 2014 dianggap telah mencabut kewenangan yang dimiliki penyidik dalam melakukan penyidikan dalam rangka mengetahui apakah telah terjadi penyalahgunaan wewenang yang dilakukan oleh seorang tersangka selaku pejabat pemerintahan yang mana menurut hal tersebut seharusnya menjadi objek untuk diuji terlebih dahulu di Peradilan Tata Usaha Negara.

Pendapat ini juga senada dengan Lie Oen Hock yang berpandangan bahwa pola penyelesaian terhadap penyimpangan dalam 
penyalahgunaan wewenang maupun sewenang-wenang adalah melalui peradilan administrasi atau Peradilan Tata Usaha Negara. Demikian pula L. J.A Damen juga berpandangan bahwa ada tidaknya unsur penyalahgunaan wewenang harus diuji dengan asas spesialitas (specialiteitsbeginsel) yakni asas yang menentukan bahwa wewenang itu diberikan kepada organ pemerintahan dengan tujuan tertentu.(Indriyanto Seno Adji,2009:10)

Secara substansial, asas spesialitas (specialialiteit beginsel) mengandung makna bahwa setiap kewenangan memiliki tujuan tertentu. Penyimpangan terhadap asas ini akan melahirkan penyalahgunaan kewenangan (detournement de pouvoir). Parameter peraturan perundang-undangan maupun asas-asas umum pemerintahan yang baik dipergunakan untuk membuktikan instrumen atau modus penyalahgunaan kewenangan (penyalahgunaan kewenangan dalam Pasal 3 UU 20 Tahun 2001 tentang PTPK), sedangkan penyalahgunaan kewenangan baru dapat diklasifikasikan sebagai tindak pidana apabila berimplikasi terhadap kerugian negara atau perekonomian negara (kecuali untuk tindak pidana korupsi suap, gratifikasi, dan pemerasan), tersangka mendapat keuntungan, masyarakat tidak dilayani, dan perbuatan tersebut merupakan tindakan tercela.

Adanya mekanisme pengujian melalui Peradilan Tata Usaha Negara terkait ada atau tidak adanya unsur penyalahgunaan wewenang juga inheren dengan asas Ultimum Remedium dalam hukum pidana, di mana keberadaan pengaturan sanksi pidana harus diletakkan atau diposisikan sebagai sanksi terakhir.( Yulies Masriani Tiena,2006:63) .Asas Ultimum Remedium dalam penerapan hukum pidana menjadi sangat penting terlebih manakala upaya diskresi di dalam pengambilan keputusan yang dilakukan oleh seorang pejabat publik kerap dijadikan senjata lawan politiknya untuk menyerang pejabat tersebut.

\section{Pengaturan Penyalahgunaan Wewenang} Pemerintah dalam Undang-Undang

\section{Nomor 20 Tahun 2001 Tentang Tindak Pidana Korupsi.}

Dalam Undang-Undang Nomor 31 Tahun 1999 sebagaimana telah diubah oleh Undang-Undang Nomor 20 Tahun 2001 tentang Pemberantasan Tindak Pidana Korupsi tidak ditemukan rumusan atau definisi apa sebenarnya yang dimaksud dengan tindak pidana korupsi. Namun demikian, mengingat kedua undang-undang ini adalah undang-undang yang saat ini berlaku (hukum positif) maka tidak salahnya apabila pada bagian ini diuraikan tipologi atau bentuk perbuatan yang dapat dikategorikan sebagai tindak pidana korupsi menurut kedua undang-undang ini. Tidak ada definisi baku dari tindak pidana Korupsi. Akan tetapi secara umum, pengertian tindak pidana korupsi adalah suatu perbuatan curang yang merugikan keuangan negara. Atau penyelewengan atau penggelapan uang negara untuk kepentingan pribadi dan orang lain.( Aziz Syamsuddin,2011:15)

Pengertian korupsi menurut hukum Indonesia, tidak dijelaskan dalam pasal pertama UU Korupsi seperti undangundang lainnya. Maka dari itu, untuk mengetahui apa yang dimaksud dengan korupsi, harus dilihat dalam rumusan pasalpasal UU Korupsi, yaitu sekitar 13 pasal yang mengaturnya serta terdapat tiga puluh jenis tindakan yang dapat dikategorikan sebagai korupsi. Dalam Undang-undang Republik Indonesia Nomor 20 Tahun 2001 Tentang Pemberantasan Tindak Pidana Korupsi, Pasal 3 menyebutkan tindak pidana Korupsi adalah :

"Setiap orang yang dengan tujuan menguntungkan diri sendiri atau orang lain atau suatu korporasi, menyalahgunakan kewenangan, kesempatan atau sarana yang ada padanya karena jabatan atau kedudukan yang dapat merugikan keuangan negara atau perekonomian negara, dipidana dengan pidana penjara seumur hidup atau pidana penjara paling singkat 1 (satu) tahun dan paling lama 20 (dua puluh) tahun dan atau denda paling sedikit Rp50.000.000,00 (lima puluh juta 
rupiah) dan paling banyak Rp1.000.000.000,00 (satu milyar rupiah).

Jika diperhartikan rumusan delik Pasal 3 PTPK terdapat frase " "kesempatan” yaitu peluang dapat dimanfaatkan oleh pelaku tindak pidana peluang mana tercantum di dalam ketentuan-ketentuan tentang tata kerja yang berkaitan dengan jabatan atau kedudukan yang dijabat atau diduduki oleh pelaku tindak pidana korupsi. Pada umumnya kesempatan ini diperoleh atau didapat dari ketentuan-ketentuan tentang tata kerja tersebut atau kesengajaan menafsirkan secara salah terhadap ketentuan-ketentuan tersebut.

Frasa berikutnya adalah "menyalahgunakan sarana yang ada pada jabatan atau kedudukan dari pelaku tindak pidana korupsi". Sarana dapat diartikan sebagai syarat, media atau cara. Dalam kaitannya dengan ketentuan tentang tindak pidana korupsi, jabatan menurut Utrecht adalah suatu lingkungan pekerjaan tetap yang diadakan dan dilakukan guna kepentingan Negara/kepentingan umum atau yang dihubungkan denagn organisasi sosial tertinggi yang diberi nama Negara.

Sedangkan mengenai kedudukan menurut Soedarto, istilah kedudukan di samping kata jabatan adalah sangat meragukan.Kalau kedudukan ini diartikan sebagai fungsi pada umumnya, maka seorang direktur bank swasta juga mempunyai kedudukan. Maka kedudukan dalam perumusan tindak pidana korupsi dalam Pasal 3 dipergunakan untuk pelaku tindak pidana korupsi bagi pegawai negeri dan bukan pegawai negeri, yaitu sebagai pelaku tindak pidana korupsi yang tidak memangku suatu jabatan tertentu, baik jabatan structural maupun jabatan fungsional.( Robertus Dicky Armando,2020:12)

Sayangnya, pada penjelasan pasal ini tidak menjelaskan maksud dari "menyalahgunakan wewenang". Disitu hanya menjelaskan bahwa kata "dapat" sebelum frasa "merugikan keuangan atau perekonomian Negara" diartikan sama dengan penjelasan Pasal 2 UndangUndang Pemberantasan Tipikor, yakni tindak pidana korupsi merupakan delik formil, yaitu adanya tindak pidana korupsi cukup dengan dipenuhinya unsur-unsur perbuatan yang sudah dirumuskan bukan dengan timbulnya akibat.

Namun berdasarkan sebuah paparan yang dibuat oleh pusat penerangan kejaksaan agung republik indonesia yang berjudul peran pegawai pemerintah sebagai partisipan dalam membangun budaya hukum bangsa menjelasakan antara lain bahwa penyalahgunaan wewenang mengacu pada undang-undang pemberantasan tindak pidana korupsi (Tipikor) adalah menyalahgunakan wewenang, kesempatan atau sarana yang melekat padanya karena jabatan atau kedudukannya yang dapat merugikan Negara atau perekonomian Negara.

Puspenkum Kejagung juga menjelaskan arti penyalahgunaan wewenang menurut UU PemberantasanTipikoryaitu,(https://www. hukumonline.com/klinik/detail/ulasan/lt54 fbbf142fc22/arti-menyalahgunakanwewenang-dalam-tindak-pidana-korupsi/ 1. Melanggar aturan tertulis yang menjadi dasar kewenangan;

2. Memiliki maksud yang menyimpang walaupun perbuatan sudah sesuai dengan peraturan;

3. Berpotensi merugikan negara.

Jadi tindakan menyalahgunakan wewenang dalam melakukan tindak pidana korupsi tidak harus selalu berupa dikeluarkannya keputusan yang bertentangan atau menyalahi suatu aturan.Cukup perbuatan itu melanggar aturan tertulis sebagai dasar kewenangannya, memiliki maksud yang menyimpang, dan berpotensi merugikan Negara, maka perbuatan tersebut sudah dikatakan sebagai menyalahgunakan wewenang.

Tindak pidana korupsi dalam berbagai bentuk pada dasarnya terjadi sejak lama dengan pelaku mulai dari pejabat negara sampai pegawai yang paling rendah. Marwan Mas mengklarifikasikan setidaknya 7 (tujuh) bentuk dan 30 jenis perbuatan korupsi (diatur dalam 13 pasal 
UU Korupsi), mulai dari Pasal 2 sampai Pasal 12B UU Korupsi, kecuali Pasal 4 dan Pasal 12A sebagai berikut.( Marwan Mas,2014:35)
1. Kerugian Keuangan/Perekonomian Negara
2. Suap - Menyuap (sogokan atau pelicin)
3. Penggelapan dalam Jabatan
4. Pemerasan
5. Perbuatan Curang
6. Benturan kepentingan dalam pengadaan.
7. Gratifikasi (pemberian hadiah)

\section{Bentuk Penyalahgunaan Wewenang Yang Dilakukan Oleh Pemerintah Dalam Kontrak Pengadaan Barang Dan Jasa}

Dalam Peraturan Presiden (Perpres) Nomor 4 tahun 2015 menerangkan salah satu tugas Pejabat Pembuat Komitmen (PPK) adalah pejabat yang bertanggungjawab atas pelaksanaan barang dan jasa. Sehingga agar dalam kontrak tidak terjadi banyak kesalahan, PPK membutuhkan sedikit keahlian tentang penyusunan kontrak.Penyusunan kontrak tentunya dimulai dengan perancangan kontrak.PPK dapat dibantu oleh ataupun tenaga ahli dalam menyusun rancangan kontrak.

Tentunya dalam rancangan kontrak syarat-syarat sah suatu kontrak seperti yang sudah ditetapkan dalam pasal 1320 Kitab Undang-Undang Hukum Perdata (KUHPerdata) harus sudah terakomodasi di dalamnya supaya kontrak tidak mempunyai celah untuk dibatalkan demi hukum apabila syarat-syarat subyektif tidak dipenuhi atau dapat dibatalkan jika syarat-syarat obyektif tidak dipenuhi.Selain itu dalam pengadaan barang/jasa Pemerintah, diatur jugamengenai Pakta Integritas, yang didalamnya adalah surat pernyataan yang berisi ikrar untuk mencegah dan tidak melakukan kolusi, korupsi dan nepotisme dalam pengadaan barang dan jasa.

Pakta Integritas sebagai bagian tak terpisahkan dari pilar-pilar good governance untuk memastikan para pihak dapat menjalankan hak dan kewajibannya tanpa merubah sistem hukum yang ada. Selain itu juga meningkatkan transparansi, akuntabilitas, partisipasi masyarakat, nilainilai kejujuran yang akan mendorong terciptanya persaingan usaha yang sehat, iklim investasi yang baik dan mencegah praktik penyimpangan.

Potensi Pelanggaran dalam kegiatan pengadaan barang/jasa dapat terjadi dalam bentuk yaitu penetapan calon pemenang yang tidak lengkap lampiran-lampiran evaluasinya, pada tahap penunjukan pemenang yang terjadi dalam bentuk surat penunjukan yang tidak lengkap, meliputi berita acara evaluasi, baik administratif dan teknis, beserta lampiran-lampiran lembar evaluasinya, surat penunjukan yang sengaja dikeluarkan penundaannya, surat penunjukan yang dikeluarkan secara terburu-buru, dan surat penunjukan yang tidak sah.

Kemudian dalam tahap penandatangan kontrak, potensi pelanggaran dapat terjadi dalam bentuk yaitu penandatanganan kontrak ditundatunda dan penandatanganan kontrak dilakukan secara tertutup. Sementara pada tahap Penyerahan Barang dan Jasa, potensi pelanggaran dapat terjadi dalam bentuk volume masing-masing pekerjaan tidak sama dan tidak sinkron dengan dokumen penawaran dan kontrak, kualitas pekerjaan yang rendah dari ketentuan yang diatur dalam spesifikasi teknis dan atau dalam lembar usulan teknis, dan kualitas pekerjaan yang tidak sama dengan spesifikasi teknis.

\section{Kesimpulan}

Berdasarkan uraian pada bagian pembahasan diatas, maka dapat ditarik kesimpulan sebagai berikut:

1. Tindakan penyalahgunaan wewenang dalam undang-undang No 30 Tahun 2014 dikategorikan sebagai tindakan yang menyimpang dari tujuan atau maksud dari suatu pemberian kewenangan; menyimpang dari tujuan atau maksud dalam kaitannya dengan asas legalitas; dan menyimpang dari tujuan atau maksud dalam kaitannya dengan asas-asas umum pemerintahan yang baik, sementara dalam undang-undang no 20 tahun 2001 
penyalahgunaan wewenang dikategorikan sebagai perbuatan yang melanggar aturan tertulis sebagai dasar kewenangannya, memiliki maksud yang menyimpang, dan berpotensi merugikan Negara

2. Potensi Pelanggaran dalam kegiatan pengadaan barang/jasa dapat terjadi dalam tahap penunjukan pemenang yang terjadi dalam bentuk surat penunjukan yang tidak lengkap, meliputi berita acara evaluasi, baik administratif dan teknis, beserta lampiran-lampiran lembar evaluasinya, dalam tahap penandatangan kontrak dimana penandatanganan kontrak dilakukan secara tertutup dan tahap Penyerahan Barang dan Jasa, potensi pelanggaran dapat terjadi dalam bentuk volume masing-masing pekerjaan tidak sama dan tidak sinkron dengan dokumen penawaran dan kontrak.

\section{UCAPAN TERIMA KASIH}

Atas terlaksananya penelitian ini, tidak lupa kami sampaikan kepada kampus Institut Ilmu Sosial dan Ilmu Budaya Samawa Rea (IISBUD SAREA) yang telah memberikan dana, sehingga penelitian ini selesai dan berjalan sesuai dengan waktu yang telah ditetapkan

\section{DAFTAR PUSTAKA}

\section{Buku}

Donal Fariz, dkk., Kajian Implementasi Aturan Trading in Influence dalam Hukum Nasional, Indonesia Corruption Watch, Jakarta, 2014

Johny Ibrhim , penelitian hukum, Kencana, Jakarta, 2010

Soerjono Soekanto dan Sri Mamuji, PenelitianHukum Normatif Suatu Tinjauan Singkat, Raja Grafindo Persada, Jakarta, 2010

Indriyanto Seno Adji, Korupsi dan Penegakan Hukum, Jakarta: Diadit Media, 2009

Philippus M. Hadjon dkk, Pengantar Hukum Administrasi Negara, Yogyakarta: Gajah Mada University Press, 2001

Yulies Masriani Tiena, Pengantar Hukum Indonesia, Cetakan II, Jakarta: Sinar Grafika, 2006
Aziz Syamsuddin, Tindak Pidana Khusus, Jakarta: Sinar Grafika, 2011

Marwan Mas, Pemberantasan Tindak Pidana Korupsi, Jakarta : Ghalia Indonesia, 2014

Jurnal

Beridiansyah" Analisis Yuridis Terhadap Pengadaan Barang dan Jasa Guna Mencegah Korupsi" jurnal integritas , Volume 3 Nomor 2 - Desember 2017

Intan Mayasari dkk, Tinjauan Yuridis Terhadap Penylahgunaan Wewenang Dalam Jabatan Menurut Undang-Undang Tipikor Studi Kasus Putusan Pengadilan Tipikor Semarang SMG No. 123 / Pidsus / 2012 / Pn. Tipikor. SMG, jurnal diponegoro law journal, Volume 5, Nomor 3, Tahun 2016,

Murdian,Tangung Jawab Pidana Dalam Pelaksanaan Kontrak Pengadaan Barang Dan Jasa Pemerintah, jurnal IUS, Volume IV, nomor 1 Tahun 2016

Robertus Dicky Armando et all, Analisa Yuridis Tentang Penyalahgunaan Wewenang Dalam Tindak Pidana Korupsi Berdasarkan UndangUndang Nomor 20 Tahun 2001, Ejurnal Ilmu Hukum Kertha Wicara, Volume 9, nomor 2Tahun 2020

\section{Undang-undang}

Undang-undang No 30 Tahun 2014 Tentang Administrasi Pemerintahan

Undang-undang No 20 Tahun 2001 Tentang Tindak Pidana Korupsi

Peraturan Presiden (Perpres) Nomor 4 tahun 2015 Tentang Pengadaan Barang dan Jasa

\section{Internet}

https://globalfmlombok.com/read/2015/08/11/ kasus-tpa-ksb-satu-orang-tersangka ditahan.htm

http://www.hukumonline.com/berita/baca/lt53 1b60851cc21/akademisi--pengambilkebijakan-publik-tak-dapat-dipidana https://www.hukumonline.com/klinik/detail/u lasan/lt54fbbf142fc22/artimenyalahgunakan-wewenang-dalamtindak-pidana-korupsi/ 